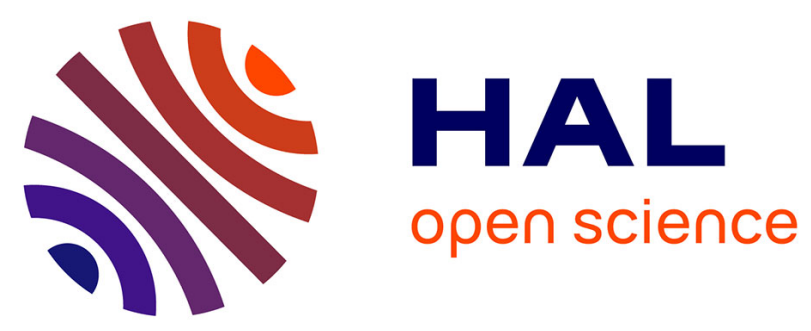

\title{
Hypoxia, via stabilization of hypoxia-inducible factor HIF-1alpha is a direct and sufficient stimulus for brain-type natriuretic peptide induction
}

Alexander Weidemann, Bernd Klanke, Michael Wagner, Tilmann Volk, Carsten Willam, Michael S. Wiesener, Kai Uwe Eckardt, Christina Warnecke

\section{To cite this version:}

Alexander Weidemann, Bernd Klanke, Michael Wagner, Tilmann Volk, Carsten Willam, et al.. Hypoxia, via stabilization of hypoxia-inducible factor HIF-1alpha is a direct and sufficient stimulus for brain-type natriuretic peptide induction. Biochemical Journal, 2007, 409 (1), pp.233-242. 10.1042/BJ20070629 . hal-00478800

\section{HAL Id: hal-00478800 https://hal.science/hal-00478800}

Submitted on 30 Apr 2010

HAL is a multi-disciplinary open access archive for the deposit and dissemination of scientific research documents, whether they are published or not. The documents may come from teaching and research institutions in France or abroad, or from public or private research centers.
L'archive ouverte pluridisciplinaire HAL, est destinée au dépôt et à la diffusion de documents scientifiques de niveau recherche, publiés ou non, émanant des établissements d'enseignement et de recherche français ou étrangers, des laboratoires publics ou privés. 
Hypoxia, via stabilization of hypoxia-inducible factor HIF-1 $\alpha$ is a direct and sufficient stimulus for brain-type natriuretic peptide induction

Alexander Weidemann ${ }^{1,2}$, Bernd Klanke ${ }^{1}$, Michael Wagner ${ }^{3}$, Tilmann Volk ${ }^{3}$ Carsten Willam ${ }^{1}$, Michael S. Wiesener ${ }^{1,2}$, Kai-Uwe Eckardt ${ }^{1}$, Christina Warnecke ${ }^{1}$

${ }^{1}$ Department of Nephrology and Hypertension, University of Erlangen-Nuremberg

${ }^{2}$ Interdisciplinary Centre for Clinical Research (IZKF), and

${ }^{3}$ Institute of Cellular and Molecular Physiology, University of Erlangen-Nuremberg

Running title: BNP is a novel target gene of HIF- $1 \alpha$.

Corresponding author:

Alexander Weidemann, M.D.

Department of Nephrology and Hypertension

University of Erlangen-Nuremberg

Krankenhausstr. 12

91054 Erlangen

Tel.: +49.9131 .8536311$

Fax.: +49.9131.8539202

E-Mail: aweidemann@ucsd.edu

Word count (including references and figure legends): 8221 words 


\section{Abstract}

Brain-type Natriuretic Peptide (BNP) is a cardiac hormone with systemic hemodynamic effects as well as local cytoprotective and antiproliferative properties. It is induced under a variety of pathophysiological conditions, including decompensated heart failure and myocardial infarction. Since regional hypoxia is a potential common denominator of increased wall stretch and myocardial hypoperfusion, we investigated direct effects of hypoxia on BNP expression and the role of the hypoxia-inducible transcription factor (HIF) in $\mathrm{BNP}$ regulation.

Using RNase protection assay we found a strong hypoxic induction of BNP mRNA expression in different cell lines and in cultured adult rat cardiomyoctes. Systemic hypoxia and exposure to $0.1 \%$ carbon monoxide induced BNP expression in the rodent myocardium in vivo, yet at a low amplitude. BNP promoter-driven luciferase expression increased 10-fold after hypoxic stimulation in transient transfections. Inactivation of four putative hypoxiaresponse elements (HRE) in the promoter by site-directed mutagenesis revealed that the HRE at $-466 \mathrm{nt}$ was responsible for hypoxic promoter activation. A functional CACAG motif was identified upstream of this HRE. The HIF-1 complex bound specifically and inducibly only to the HRE at $-466 \mathrm{nt}$ as shown by EMSA and chromatin immunoprecipitation. SiRNA mediated knockdown of HIF-1 $\alpha$, but not HIF-2 $\alpha$, interfered with hypoxic BNP mRNA induction and BNP promoter activation, confirming that BNP is a specific HIF-1 $\alpha$ target gene.

In conclusion, BNP appears to be part of the protective program steered by HIF-1 in response to oxygen deprivation. Induction of BNP may therefore contribute to the potential benefits of pharmacological HIF inducers in the treatment of ischemic heart disease and heart failure. 


\section{Introduction}

Brain-type natriuretic peptide (BNP) is one of three members of the natriuretic peptide family which is predominantly expressed in the adult heart. Like the atrial natriuretic peptide (ANP) it has natriuretic, diuretic and vasodilating properties [1, 2] and acts by increasing intracellular cGMP levels via the activation of the particulate guanylyl cyclase (pGC) [3]. In addition to the systemic hemodynamic actions, BNP has antimigratory, antifibrotic and cytoprotective effects in the heart [4-6], which are suggested to constitute a counterregulatory system to attenuate the development of cardiac fibrosis in vivo [7]

BNP synthesis and secretion is induced by pathophysiological conditions such as left ventricular hypertrophy, myocardial infarction and heart failure [8-10]. Myocardial stretch is a potent inducer of BNP [11]. The contribution of tissue hypoxia as a stimulus for the induction of BNP is less clear, since most experimental approaches investigated myocardial ischemia [12, 13] or longterm hypoxic exposure of animals $[14,15]$ which are associated with far more complex pathophysiological alterations than hypoxia alone. These include changes in hemodynamics and ventricular mass which in turn can affect BNP gene expression. Hypoxic perfusion of isolated hearts increased BNP protein release, but the effect of hypoxia at the transcriptional level was not investigated [16]. In cardiac myocyte preparations the effect of hypoxia was less clear: freshly prepared porcine myocytes exhibited a less pronounced induction of a premature BNP mRNA under anoxia compared to the ischemic myocardium in vivo [17]. Moreover a recent study did not observe a hypoxic upregulation of BNP mRNA in rat and human cardiomyocytes [18]. It is therefore so far unclear, whether hypoxia constitutes a single and sufficient stimulus for BNP gene induction in vitro.

Mammalian cells respond to low oxygen with an increased expression of several hypoxiainducible genes. The master regulator of this cellular adaptation to hypoxia is the hypoxiainducible factor (HIF), a heterodimeric transcription factor which consists of the constitutively expressed $\beta$-subunit termed HIF-1 $\beta$ or ARNT and one of two alternative oxygen regulated $\alpha$-subunits, HIF- $1 \alpha$ and HIF- $2 \alpha$. In hypoxia, the $\alpha / \beta$ heterodimeric HIF complex induces transcription through interaction with the hypoxia-response elements (HREs) in the regulatory regions of target genes such as erythropoietin (EPO), heme oxygenase 1 (HO-1), vascular endothelial growth factor (VEGF) and inducible nitric oxide synthase (iNOS) (for review [19, 20]). Under normoxia the HIF- $\alpha$ subunits are rapidly 
hydroxylated at two conserved prolyl residues by specific prolyl hydroxylases (PHD1-3) [21, 22], which enables interaction with the von Hippel-Lindau (VHL) E3 ubiquitin ligase complex that targets HIF- $\alpha$ for proteasomal destruction [23]. Stimulation of HIF target genes has been shown to limit infarct size and ameliorate ventricular function in experimental models of myocardial ischemia [24]. We recently demonstrated that both HIF- $\alpha$ isoforms were stabilized in the hypoxic or infarcted myocardium, and that HIF target genes were induced in the perinecrotic areas, which may limit hypoxic damage $[25,26]$. Whether BNP was part of this HIF mediated response was not investigated. Gene expression profiling studies [27, 28] suggested an involvement of HIF-1 in BNP expression, but since these studies were based on overexpression of stable HIF-mutants, the role of hypoxia and the individual contribution of the two HIF- $\alpha$ isoforms remained unknown.

Given the increasingly recognized significance of low oxygen as a regulator of cell function and its potential role in BNP regulation, we decided to study direct effects of hypoxia and the activation of the HIF system on BNP expression in vitro and in vivo. We provide evidence herein that BNP mRNA expression is directly regulated by molecular oxygen and that this regulation is mediated by interaction of endogenous HIF-1 $\alpha$ with one of four potential HREs in the proximal 5' regulatory region of the human BNP gene. 


\section{Material and Methods}

Cells and reagents. Hep3B and HepG2 human hepatoma cells were purchased from ATCC (Manassas, VA), mouse fibroblastoid preadipocyte 3T3L1 cells were a gift from M. Praus, Berlin and murine embryonic fibroblasts (MEF) were a kind gift of G. Semenza, Baltimore. HKC-8 cells were generously provided by L. Racusen, Baltimore. Cell culture reagents were from PAA, Invitrogen and Biochrom. 2,2'dipyridyl was purchased from ICN. All other chemicals were from Sigma. The plasmid 6xHRE/tk/luc was a kind gift from P. Ratcliffe, Oxford, UK, and HIF-2 $\alpha$ antibody PM9 from P. Maxwell, London, UK.

Cell culture.Cell lines were grown in Dulbecco's modified Eagle's medium supplemented with $10 \%$ FCS, 2 mM L-glutamine, $100 \mathrm{U} / \mathrm{ml}$ penicillin and $100 \mu \mathrm{g} / \mathrm{ml}$ streptomycin. HKC-8 cells were cultured in DMEM/Ham's F-12 containing $5 \mu \mathrm{g} / \mathrm{ml}$ insulin, $5 \mu \mathrm{g} / \mathrm{ml}$ transferrin, 5 $\mathrm{ng} / \mathrm{ml}$ sodium selenite. For the analyses of BNP mRNA induction in vitro, cells were exposed to $1 \%$ oxygen in a Jouan IG 750 water-jacketed incubator (Thermo Electron) or stimulated with the hypoxia mimetic $2,2^{\prime}$ dipyridyl at a concentration of $100 \mu \mathrm{M}$ for $16 \mathrm{~h}$.

Animal experiments. All animal experiments were approved by local government authorities (Government of Mittelfranken) and conform with the Guide for the Care and Use of Laboratory Animals published by the US National Institutes of Health (NIH Publication No. 85-23, revised 1996). Three six-week-old male Sprague Dawley rats and three six-week-old C57BL/6 mice were exposed to $0.1 \%$ carbon monoxide or to $8 \% \mathrm{O}_{2}$ in a hypoxia workbench (In Vivo 400, Ruskin Technology). After $10 \mathrm{~h}$, the animals were sacrificed by cervical dislocation and tissue was frozen in liquid nitrogen for RNA analysis.

Isolation and hypoxic stimulation of myocytes. For myocyte isolation male Wistar rats were anaesthetised and the heart was quickly excised and placed into icecold Tyrode's solution $\left(138 \mathrm{mM} \mathrm{NaCl}, 4 \mathrm{mM} \mathrm{KCl}, 0.9 \mathrm{mM} \mathrm{CaCl}_{2}, 1 \mathrm{mM} \mathrm{MgCl}, 0.33 \mathrm{mM} \mathrm{NaH} \mathrm{PO}_{4}, 10\right.$ mM glucose, 1 mM EGTA, 10 mM HEPES, $1 \mu \mathrm{M}$ insulin (Sigma); pH 7.30). The ascending aorta was cannulated, the heart was mounted on a Langendorff apparatus and ventricular myocytes were isolated as described previously [29, 30]. Briefly, the heart was perfused with Tyrode's solution for five minutes at $37^{\circ} \mathrm{C}$. Perfusion pressure was $75 \mathrm{mmHg}$, and all solutions were equilibrated with $100 \%$ oxygen. Then the hearts were perfused with Tyrode's solution containing collagenase (type CLS II, $160 \mathrm{U} / \mathrm{ml}$ (Biochrom)) and protease (type XIV, 
$0.5 \mathrm{U} / \mathrm{ml}$ (Sigma)), and finally with modified storage solution (130 mM NaCl, $5.4 \mathrm{mM} \mathrm{KCl}$, $1 \mathrm{mM} \mathrm{CaCl}_{2}, 0.5 \mathrm{mM} \mathrm{MgCl}_{2}, 0.4 \mathrm{mM} \mathrm{NaH}_{2} \mathrm{PO}_{4}, 22 \mathrm{mM}$ glucose, $5.8 \mathrm{mM} \mathrm{NaHCO} 3,25 \mathrm{mM}$ HEPES, $1 \mu \mathrm{M}$ insulin and $1 \mathrm{mg} / \mathrm{ml}$ BSA (Merck); pH 7.40). Ventricular myocytes were isolated by mincing the tissue and gentle mechanical agitation. After a preplating step to eliminate fibroblasts they were plated in storage solution containing antibiotics. Cells were kept for $6 \mathrm{~h}$ before being exposed to hypoxia (1\% oxygen) for $10 \mathrm{~h}$.

RNA preparation and RNase protection assay. Tissue was homogenized using an Ultraturrax homogenizer (IKA) and total RNA was extracted with RNAzol B (Biozol) and analyzed by RNase protection assay essentially as described previously [31]. Riboprobe templates for human, murine and rat BNP mRNA were generated by PCR using oligonucleotides based on published sequences (human: NM002521, nt 232-387; mouse: NM008726, nt 136-313; rat: NM031545, nt 118-289) and cloned into pcDNA3 (Invitrogen) using generated 5' KpnI and 3'XhoI restriction sites (primers see Supplemental Table 1). Quantification of signal intensities was performed using a Phosphoimager (FujiBAS 2000, Kodak). Data given represent the means of three independent experiments \pm SD.

\section{Cloning of hBNP promoter luciferase reporter plasmids and generation of HRE and}

CACAG mutants. The human BNP 5'-flanking sequence (acc. no. U34833) was analysed for putative hypoxia-responsive elements (HRE) using the MatInspector software at www.genomatix.de. A 2027-bp and a 967-bp promoter fragment including exon 1 were amplified from human genomic DNA (primers see Supplemental Table 1) and cloned into the pGL2 basic luciferase vector (Promega) yielding the plasmid hBNP-Prom(L) and hBNPProm, respectively. Four BNP-promoter luciferase constructs with mutations in each of the four putative HREs or the CACAG motif were generated by site-directed mutagenesis using the hBNP-Prom (967-bp) plasmid as template and Combi-Pol DNA Polymerase Mix (Invitek). For primer sequences see Supplemental Table 2. Successful cloning of all reporter constructs was verified by sequencing.

Luciferase reporter gene assays. Hep3B cells were cultured in 24-well plates to 50\% confluency and transfected with $300 \mathrm{ng} /$ well of the respective luciferase reporter plasmid and $30 \mathrm{ng}$ of a pCMV- $\beta$-galactosidase expression vector using Fugene ${ }^{\circledR}$ transfection reagent (Roche). Transfected cells were stimulated for $18 \mathrm{~h}$ with hypoxia $\left(1 \% \mathrm{O}_{2}\right)$ or $100 \mu \mathrm{M}$ 
2,2'dipyridyl (DP). For HIF- $\alpha$ knockdown analyses the plasmid-transfected cells were cotransfected with siRNAs as described below. Luciferase activities were normalized to the respective $\beta$-galactosidase expression. All transfections were performed in triplicates. Data represent the means of three independent experiments \pm SD.

siRNA transfection. HIF- $1 \alpha$ and HIF- $2 \alpha$ siRNA sequences were the same as described previously [32] and were synthesized by Xeragon/Qiagen. As a negative control we used a siRNA targeting the firefly luciferase coding sequence [33]. Cells were transfected with siRNAs (final concentration $200 \mathrm{nM}$ ) at $60-75 \%$ confluency by the use of Oligofectamine in serum-free Optimem ${ }^{\circledR}$ medium (both Invitrogen) according to the protocol of the supplier. Medium was changed $14 \mathrm{~h}$ post-transfection and the cells were stimulated with $100 \mu \mathrm{M}$ DP for $18 \mathrm{~h}$.

Preparation of cell lysates and immunoblotting. Protein extraction and immunoblotting were performed as described previously [34]. Briefly, after siRNA transfection and stimulation with DP for $8 \mathrm{~h}$ Hep3B and HKC-8 cells were lysed in $8 \mathrm{M}$ urea, $10 \%$ glycerol, 10 mM Tris-HCl (pH 6.8), 1\% SDS, 5 mM DTT, and protease inhibitors Complete ${ }^{\circledR}$ (Roche). $100 \mu \mathrm{g}$ of protein was separated on $8 \%$ polyacrylamide gels, transferred onto PVDF membranes (Millipore) and incubated with antibodies against HIF-1 $\alpha$ (Affinity Bioreagents) and HIF-2 $\alpha$ (PM 9). Subsequently blots were exposed to HRP-conjugated secondary antibodies (Dako) and signals were visualised by chemiluminescence (SuperSignal West Dura Extended $^{\circledR}$; Pierce).

Electrophoretic mobility shift assay (EMSA). Hep3B cells were exposed to normoxia, 1\% $\mathrm{O}_{2}$ or to $100 \mu \mathrm{M}$ DP and nuclear extracts were prepared using a modified Dignam protocol as described previously [23]. $5 \mu \mathrm{g}$ of nuclear protein were incubated with $10^{5}$ c.p.m. of a $\left[{ }^{32} \mathrm{P}\right]-$ labelled 24-bp double-stranded oligonucleotide probe (see Supplemental Table 3). For supershift assays the binding reaction was preincubated with $0.5 \mu \mathrm{g}$ of an anti-HIF-1 $\alpha$ monoclonal antibody (Transduction Laboratories, USA) for $30 \mathrm{~min}$ before addition of the labelled probe.

Chromatin immunoprecipitation. Hep3B cells were exposed to $100 \mu \mathrm{M}$ DP overnight and then treated with $1 \%$ formaldehyde for $15 \mathrm{~min}$ at room temperature. Cells were washed and 
harvested in cold PBS, lysed in $50 \mathrm{mM}$ TrisHCl pH 8, 2 mM EDTA, 1\% SDS, protease inhibitors Complete ${ }^{\circledR}$, and sonicated to shear the DNA to fragments of approximately 600 bps. $1 / 10$ of the lysate was stored as input control. To the remaining cell lysates four volumes of 1.25x RIPA buffer (50 mM TrisHCl pH 7.5, 0.1\% sodium deoxycholate, $0.625 \%$ NP40, 2 mM EDTA, $200 \mathrm{mM} \mathrm{NaCl}$, protease inhibitors Complete ${ }^{\circledR}$ ) was added. The diluted lysate was then precleared with protein A agarose for $1 \mathrm{~h}$ at $4^{\circ} \mathrm{C}$. The supernatant was split into two, and one half was incubated with unspecific rabbit IgG and the other with $2 \mu \mathrm{g}$ of a HIF-1 $\alpha$ or HIF-2 $\alpha$ rabbit polyclonal antibody (Novus Biologicals) for $1 \mathrm{~h}$. Then, protein A agarose preblocked with bovine serum albumin and Herring sperm DNA was added and incubation was continued for further $4 \mathrm{~h}$ at $4^{\circ} \mathrm{C}$. Beads were washed $2 \times 15 \mathrm{~min}$ in RIPA buffer, $1 \times 15$ min in high salt RIPA buffer $(1 \mathrm{M} \mathrm{NaCl})$, and 2 x 5 min with $10 \mathrm{mM}$ Tris- $\mathrm{HCl}, \mathrm{pH} 8.0 / 1$ mM EDTA.

Cross-linking was reversed and DNA eluted by resuspending pellets in $200 \mu 1$ SDS-NaClDTT buffer (62.5 mM Tris $\mathrm{HCl} \mathrm{pH} 6.8,200 \mathrm{mM} \mathrm{NaCl}, 2 \%$ SDS, $10 \mathrm{mM}$ DTT) and incubation at $65^{\circ} \mathrm{C}$ overnight. DNA was prepared by phenol/chloroform extraction, precipitated, and dissolved in $10 \mathrm{mM}$ Tris- $\mathrm{HCl} \mathrm{pH}$ 8.0. PCR reactions were carried out using a primer pair which flanked HRE 2 of the BNP promoter (primer sequences see Supplemental Table 4) and yielded a PCR product of 194 bps. Carbonic anhydrase IX (CA9) was used as a positive control, and $\beta$-actin which does not contain an HRE, as negative control. Both PCRs were run with 34 cycles.

Statistical analysis. Data were analysed by Student's $t$-test. A p-level $<0.05$ was considered significant. 


\section{Results}

Induction of BNP expression in different human and animal cell lines in response to hypoxia and 2,2’dipyridyl.

Previous reports indicated that cardiac cells in culture apparently loose the ability of hypoxic induction of BNP expression [27]. We therefore screened a number of immortalised cell lines for basal and hypoxia-inducible BNP expression including human hepatoma cells (Hep3B and HepG2), cervical carcinoma HeLa cells, human proximal tubular epithelial HKC-8 and mouse preadipocyte 3T3L1 cells. To investigate the hypoxic regulation of BNP mRNA expression cells were exposed to $1 \%$ oxygen or the iron chelator and chemical HIF inducer 2,2'dipyridyl (DP) for $16 \mathrm{~h}$. In all cell lines except HeLa, which did not express BNP mRNA at detectable levels, BNP mRNA expression was strongly induced by both stimuli (Figure 1A). Moreover, in HKC-8 and Hep3B cells BNP mRNA induction by DP was already visible after $4 \mathrm{~h}$ of stimulation (Figure 1B).

\section{Upregulation of BNP mRNA by hypoxia in cultured adult rat cardiomyoctes.}

Although BNP mRNA abundance in the heart is high in vivo, a hypoxic upregulation of BNP mRNA in cultured neonatal cardiomyocytes in vitro could previously not be demonstrated $[18,27]$. Freshly isolated adult cardiomyocytes from the left ventricle of rat hearts were exposed to $1 \%$ oxygen for $10 \mathrm{~h}$. In four independent experiments BNP mRNA expression was moderately but significantly induced $(1.7 \pm 0.3$ fold vs. normoxic cells, $p<0.05$; Figure 1C), which indicates that the response of the BNP gene to hypoxia is detectable, but operates at a lower amplitude compared to tumor cell lines. Cultured primary rat and porcine cardiac fibroblasts did not express BNP mRNA at levels detectable by RNase protection (data not shown).

\section{Exposure to 0.1\% carbon monoxide and systemic hypoxia induce BNP expression in} vivo.

To elucidate whether systemic hypoxia, in the absence of any ischemic injury to the heart, is sufficient to induce BNP mRNA levels in vivo, rats and mice were exposed to $0.1 \%$ carbon monoxide (CO) or $8 \%$ oxygen for $10 \mathrm{~h}$. $\mathrm{CO}$ exposure induces tissue hypoxia by blocking oxygen transport capacity of red blood cells and leads to a robust HIF induction in vivo [35] BNP mRNA expression was upregulated $3.4 \pm 0.1$ fold and $1.7 \pm 0.3$ fold after $\mathrm{CO}$ exposure in rat and mouse hearts, respectively $(n=3, p<0.05$; Figure 1D). In rats exposed to $8 \%$ oxygen 
a less marked increase of cardiac BNP mRNA abundance was detectable ( $1.4 \pm 0.1$ fold, $n=3$, $\mathrm{p}<0.05$; Supplemental Figure 1E).

\section{The human BNP promoter is activated by hypoxia and contains a functional HRE at -} 466 nt.

Sequence analysis of the human BNP promoter revealed six putative hypoxia-response elements (HREs) within a 2-kb region upstream of the transcriptional start site (Table 1). Hep3B cells were transiently transfected with the 2027-bp construct hBNP-Prom(L) and stimulated with $1 \% \mathrm{O}_{2}$ or $100 \mu \mathrm{M}$ DP for $18 \mathrm{~h}$. Hypoxia and DP increased reporter activity $2.3 \pm 0.2$ fold and $2.5 \pm 0.1$ fold, respectively ( $\mathrm{p}<0.05$ vs. unstimulated, Figure $2 \mathrm{~A}$ ). In contrast, the activity of the 5' deleted 967-bp construct hBNP-Prom, which still contained four putative HREs, was increased $10.3 \pm 1.3$ fold and $11 \pm 1.5$ fold after hypoxia and DPstimulation, respectively ( $p<0.05$ vs. unstimulated; Figure $2 B$ ), indicating that the functional HREs were located in the proximal region and that putative negative-regulatory regions are present in the more distant regions. To determine which of the putative HREs was essential for the hypoxic induction, we inactivated each of the four HIF binding sequences by sitedirected mutagenesis, leaving the other three of the 5 ' deleted promoter construct intact. Mutation of the BNP-HRE 2 at $-466 \mathrm{nt}$ (aCGTGc $\rightarrow$ aTTTGc) significantly reduced the increase in reporter gene activity by hypoxia from 10.3 fold to $3.0 \pm 0.3$ fold and by DP from 11 fold to $3.7 \pm 1.1$ fold ( $\mathrm{p}<0.05$ vs. wt for both stimuli; Figure $2 \mathrm{C}$ and D). Mutation of BNPHRE 1 (cCACGg $\rightarrow$ cTATTc) reduced the induction of reporter activity after stimulation with hypoxia from $11 \pm 1.5$ fold to $6.0 \pm 0.8$ fold ( $<<0.05 \mathrm{vs}$. wt), but the induction by DP was not significantly affected. Mutation of the other two HREs (HRE 3: tCACGt $\rightarrow$ tTATTt and HRE4: $\mathrm{c} C A C G \mathrm{t} \rightarrow \mathrm{cTATT}$ ) did neither change the hypoxic nor the DP-stimulated induction of luciferase activity (Figure 2C and D). Thus mutational analysis of the four putative HREs in the proximal BNP promoter revealed that the hypoxic induction was mainly dependent on the HRE at $-466 \mathrm{nt}$.

\section{The endogenous HIF-1 complex binds to the HRE at -466 nt of the human BNP promoter.}

Gel-shift analyses were performed to investigate whether the endogenous HIF-1 complex binds to the functional HRE at -466 nt. When the $\left[{ }^{32} \mathrm{P}\right]$-labelled BNP-HRE 2 probe was incubated with nuclear extracts from hypoxic or DP-stimulated Hep3B cells a binding 
complex appeared which was not observed when extracts from normoxic cells were used or the HIF binding sequence was mutated (Figure 3A). No specific binding complex was observed with probes for HRE 1, HRE 3 and 4 (data not shown). Addition of a monoclonal anti-HIF-1 $\alpha$ antibody to the binding reaction resulted in a supershifted complex, which demonstrated that HIF- $1 \alpha$ is a component of the hypoxia-inducible binding activity (Figure 3B).

To further investigate if HIF-1 $\alpha$ binds to the native BNP promoter in vivo, chromatin immunoprecipitation (ChIP) was performed. Immunoprecipitation of chromatin complexes prepared from DP-stimulated Hep3B cells with a HIF-1 $\alpha$ antibody led to an marked enrichment of a BNP promoter fragment spanning HRE 2 (Figure 3C, upper panel). In contrast, chromatin complexes from unstimulated Hep3B cells and chromatin exposed to non-specific rabbit IgG yielded only weak bands after PCR amplification, presumably due to residual non-specific binding of DNA to protein A agarose beads. Similar to BNP, an HRE spanning fragment of the carbonic anhydrase IX (CA9) promoter was enriched by the HIF-1 $\alpha$ antibody (Figure 3C, middle panel). As negative control, a $\beta$-actin gene sequence lacking a functional HRE was amplified, which was not enriched in DP-stimulated cell lysates by the HIF-1 $\alpha$ antibody (Figure 3C, lower panel). To test whether HIF-2 $\alpha$ occupied the BNP-HRE, ChIP was also performed with a HIF-2 $\alpha$ antibody. The BNP promoter and $\beta$-actin gene fragment were not enriched by PCR (Figure 3D, upper and lower panel), but surprisingly the CA9 promoter fragment was (Figure 3D, middle panel). However, this result is in keeping with a recent study by Lau and colleagues [36] who also found selective enrichment of the HRE-containing CA9 promoter fragment in chromatin from hypoxic Hep3B cells after precipitation with a HIF- $2 \alpha$ antibody, although CA9 is a well characterized HIF-1 $\alpha$ target. These findings emphasize that ChIP does not necessarily allow conclusions concerning the function of the respective HIF- $\alpha$ isoform on the gene of interest. Rather it indicates that the transcription factor is in close proximity or a part of the transcriptional complex. However, EMSA experiments clearly demonstrated binding of HIF-1 $\alpha$ protein to HRE 2 . Thus, taken together these results corroborated the findings of the reporter assays and further support (1) that BNP is a direct transcriptional target of HIF-1, and (2) that hypoxic promoter activation is mediated by the HRE 2.

\section{BNP induction is dependent on HIF-1 $\alpha$ but not on HIF-2 $\alpha$.}


Recent reports demonstrated that target gene specificity of the HIF- $\alpha$ isoforms can be overridden by overexpression of the HIF- $\alpha$ subunits [32]. We therefore performed siRNA knockdown of endogenous HIF-1 $\alpha$ and HIF-2 $\alpha$ prior to DP-stimulation to determine the relative contribution of either HIF- $\alpha$ isoform to BNP induction. In Hep3B cells siRNA transfection substantially reduced mRNA expression of HIF-1 $\alpha$ and HIF-2 $\alpha$ (Figure 4A). Efficient knockdown of HIF -proteins was confirmed by immunoblotting (Figure 4B). Knockdown of HIF-1 $\alpha$ reduced BNP mRNA levels significantly to $58 \pm 10 \%$ of DP-induced, control siRNA-transfected levels ( $p<0.05$ vs. siLuc+DP; Figure 4A). SiRNA against HIF-2 $\alpha$ did not affect BNP mRNA expression ( $88 \pm 20 \%$ of control levels, $\mathrm{p}=$ n.s.). In HKC- 8 cells a reduction of BNP mRNA induction to $42 \pm 10 \%$ of DP-stimulated control values was also observed after knockdown of HIF- $1 \alpha$ ( $p<0.05$ vs. siLuc + DP; Figure 4 C) to but not after knockdown of HIF-2 $\alpha$ (82 $\pm 25 \%, \mathrm{p}=$ n.s.). Furthermore, activities of hBNP-promoter constructs did also respond to HIF- $1 \alpha$ knockdown in Hep3B cells. SiRNA against HIF-1 $\alpha$ reduced the DP-induced activity of the 967-bp BNP promoter construct from $9 \pm 0.5$ fold to $2.5 \pm 0.1$ fold ( $\mathrm{p}<0.05$ vs. siRNA luc, Figure 4D), whereas siRNA against HIF-2 $\alpha$ had no effect (to $10.4 \pm 1.4$ fold, n.s.).

To further support the notion that hypoxic BNP regulation is mediated by HIF-1 $\alpha$, we used mouse embryonic fibroblasts (MEF) expressing or devoid of HIF-1 $\alpha$. BNP was only inducible in HIF-1 $\alpha$ positive MEFs, but not in the HIF-1 $\alpha^{-/-}$cell line (Figure 4E) confirming that BNP mRNA induction was dependent on HIF-1 $\alpha$, but not HIF-2 $\alpha$.

\section{A functional CACAG motif upstream the HRE at $-466 \mathrm{nt}$ is required for full activation of the human BNP promoter.}

Sequence analysis revealed the presence of a CACAG motif 27 bp upstream of the HRE at 466 nt. In a previous study this sequence motif, which can also be termed HIF-1 ancillary sequence (HAS), was identified downstream of the functional HRE in the EPO enhancer [37]. To elucidate the contribution of this motif to BNP promoter function we tested the activation of a $\mathrm{hBNP}$ promoter reporter plasmid with a mutated HAS $(\mathrm{g} C A C A G \mathrm{c} \rightarrow$ $\mathrm{gAATA} A \mathrm{c})$ in transiently transfected Hep3B cells. Mutation reduced the induction of promoter activity by DP from $6.2 \pm 1.2$ fold to $3.3 \pm 0.7$ fold (wt vs. CACAG mut, $\mathrm{p}<0.05$; Figure $5 \mathrm{~A})$. This was still significantly higher than the reduction observed after mutation of the HRE at $-466 \mathrm{nt}(1.1 \pm 0.04$ fold; $\mathrm{p}<0.05)$. Mutation of both the CACAG and the HRE did not further change the promoter activation by DP $(1.4 \pm 0.4$ fold (HRE+CACAG mut) 
compared to $1.1 \pm 0.04$ fold (HRE mut), p=n.s.; Figure 5A). Binding of nuclear proteins to the HAS was then investigated by EMSA. As depicted in Figure 5B, specific binding of nuclear proteins was independent of DP stimulation. Mutation abolished the binding complex. We conclude that the CACAG sequence upstream of the HRE at $-466 \mathrm{nt}$ is necessary for the full hypoxic response of the BNP promoter in Hep3B cells, indicating that a multipartite organization of the HRE, which is observed in other HIF regulated genes, is also present in the BNP-HRE. 


\section{Discussion}

BNP has widely been recognized as a reliable and sensitive clinical marker of heart failure. Previous studies suggested that BNP levels are influenced by hypoxia, but the underlying molecular mechanisms remained largely elusive. In the present study we demonstrate that hypoxia directly stimulates BNP mRNA induction and that this induction is HIF-dependent. We identified the functional hypoxia-response element (HRE) at $-466 \mathrm{nt}$ in the 5' flanking region of the BNP gene and demonstrate that binding of endogenous HIF- $1 \alpha$ but not of HIF$2 \alpha$ is sufficient for the hypoxic transactivation of BNP. These findings add novel and important insights into the molecular regulation of BNP gene expression and might have considerable clinical implications.

In vivo increased BNP mRNA abundance was previously reported after prolonged moderate hypobaric hypoxia [15] or myocardial ischemia [17]. However the experimental settings used in these studies elicited complex pathophysiological responses such as ventricular hypertrophy or altered cardiac wall tensions which extend vastly beyond the effects of hypoxia alone. Our in vitro approach provides strong evidence that hypoxia is a direct and sufficient stimulus to induce BNP expression via binding of the endogenous HIF-1 complex to a functional HRE in the BNP promoter. In contrast to a previous report on primary neonatal cardiac cells which did not show BNP induction in hypoxia [18, 27], we demonstrate that five different non-cardiac cell lines as well as primary adult rat cardimyocytes exhibited significant hypoxia-inducible BNP expression. In addition hypoxia was a sufficient stimulus to activate BNP promoter constructs in the transformed cell lines. Although BNP expression in vivo is limited to the heart, basic regulatory mechanisms such as the HIF-dependent gene induction appear to be well conserved in transformed cells of different origins. Potential inhibitors of gene expression may be absent or downregulated and HIF transcriptionally upregulated in these cells which makes them a valuable tool to study basic mechanisms of hypoxic gene regulation. In contrast, the amplitude of BNP mRNA induction in primary rat cardiomyocytes and in rodent hearts in vivo was lower than in the transformed cells. The reasons for this reduced BNP gene activation remain to be determined, but potent inhibitors of HIF activation such as PHD 3 [38] and CITED2 [39] are expressed at high levels in the heart and might contribute to a reduced HIF response of this tissue in vivo and in cultured cardiomyocytes in vitro. In support of this notion, a significant hypoxic response including induction of classical HIF target genes and a vast increase of BNP mRNA levels could only be elicited in cultured human fetal cardiac cells by infection with an 
adenoviral expression vector for a stable HIF-1 $\alpha /$ VP16 chimeric protein, but not by hypoxia or infection with an adenoviral expression vector for wildtype HIF-1 $\alpha$ [27] Moreover, crosstalk with nonmyoctes may be needed for maximum BNP upregulation under hypoxic conditions and/or by mechanical stress [40]. In the present study, we therefore also investigated cultured rat and porcine cardiac fibroblasts, but they did not express BNP mRNA at detectable levels (data not shown).

Finally, rather than hypoxia, ischemia is the most frequent trigger of cardiac BNP induction. Thus, reactive oxygen species or inflammatory mediators may possibly amplify the hypoxic response of the BNP gene in cardiac cells by activation of transcription factors which act in an additive or synergistic manner with HIF.

The in vitro findings of an attenuated BNP response to hypoxia in cultured cardiac cells was confirmed in the present study in vivo using short term exposure of rats to hypoxia (8\% oxygen) or $0.1 \%$ carbon monoxide (CO). Interestingly the amplitude of BNP induction was lower in the hearts of hypoxic animals than in the CO-treated animals, which may in part be attributable to a more pronounced decline in blood pressure and heart rate in the hypoxic compared to the CO-treated group (data not shown). This possibly counteracted BNP induction through a reduced cardiac workload. In addition we have previously shown that CO exposure is a stronger stimulus for HIF target gene activation in vivo than hypoxia [26, 35].

Our results define HIF-1 $\alpha$ as a novel and potentially important mediator of increased BNP expression in addition to the known effect of myocyte stretch [11]. Interestingly, volume overload and mechanical strain have been shown to induce HIF-1 $\alpha$ protein and the HIF target gene VEGF in vivo [41, 42]. It is possible that a regionally reduced oxygen supply generated by increased wall stress activates the HIF system which in turn could amplify the BNP response. Mechanical stress can also directly induce HIF-1 $\alpha$ in cultured vascular smooth muscle cells [43]. Therefore an increased BNP level may be regarded as an indicator of regional myocardial hypoxia or activation of the HIF system even before the onset of clinical symptoms or reduced coronary blood flow.

We identified the HRE at $-466 \mathrm{nt}$ as the functional cis-acting element mediating the HIF response of the BNP promoter. This result was surprising given the presence of three other putative HIF binding sequences in the 967-bp and further two in the 2027-bp promoter construct, which did not contribute significantly to the hypoxic activation. The longer construct even showed a lower amplitude of induction upon hypoxic stimulation, potentially due to binding of additional inhibitory factors. The localisation of a functional HRE at $-466 \mathrm{nt}$ 
in the BNP promoter is in agreement with a recent study of Luo and coworkers [18], but in contrast to their study we did not utilize forced overexpression of HIF-1 $\alpha$ protein or a normoxically stable HIF-1 $\alpha$ /VP 16 chimeric protein to induce BNP. We demonstrate for the first time that the endogenous hypoxia-induced HIF-1 complex binds to HRE 2 in the BNP promoter in vitro by gel-shift analyses and in vivo by chromatin immunoprecipitation. This further corroborates our conclusion that the HRE at $-466 \mathrm{nt}$ is most important for the hypoxic BNP induction. We also show that the HIF- $\alpha$ isoform mediating the hypoxia-response is HIF-1 $\alpha$, whereas HIF-2 $\alpha$ has no effect on BNP induction. HIF-1 was initially identified as a hypoxia-inducible transcription factor that bound to the enhancer region of the human EPO gene [37]. Subsequent studies revealed that HIF is the master regulator in a widespread system orchestrating the cellular response of mammalian cells to hypoxia [19]. After the cloning of the second HIF- $\alpha$ subunit, HIF-2 $\alpha$ or EPAS1 [44], a number of studies were undertaken to differentiate the functional roles of the two HIF- $\alpha$ subunits [28, 32]. Until now the hypoxic induction of the vast majority of identified HIF target genes could be attributed to HIF-1 $\alpha$, whereas the function of HIF- $2 \alpha$ is still not well defined. The question which HIF$\alpha$ isoform mediates the hypoxic BNP induction is of particular relevance, because cardiomyocytes are one of the few cell types which accumulate both HIF- $\alpha$ isoforms in hypoxia in vivo [25]. Forced overexpression of the HIF- $\alpha$ subunits results in loss of target gene specificity [32], therefore this approach does not allow conclusions which HIF- $\alpha$ isoform mediates the response. In fact, the same HIF-1 $\alpha / \mathrm{VP} 16$ chimeric protein which was used to induce BNP in cardiomyocytes [18] activated the known HIF-2 $\alpha$ target gene EPO in astrocytes, whereas a plasmid expressing stable HIF-1 $\alpha$ did not [45]. These findings demonstrate that under certain circumstances the physiological regulation can be overridden. We applied RNA interference at BNP promoter constructs and at the endogenous gene to dissect the contribution of the two HIF- $\alpha$ subunits to BNP regulation. These experiments together with the EMSA revealed unambiguously that BNP induction is dependent on HIF$1 \alpha$ and not $\mathrm{HIF}-2 \alpha$.

Interestingly a CACAG sequence motif is present upstream the only functional HRE at -466 nt. Thus the BNP-HRE exhibits an organization similar to the EPO-HRE [37] and VEGFHRE [46]. Mutational analysis in reporter constructs revealed that this CACAG sequence is functional and required for full hypoxic activation of the BNP promoter. The binding of nuclear protein to the CACAG motif was not inducible by DP, which is in keeping with the notion that the binding protein is expressed constitutively. The CACAG motif was previously 
described to be without effects on BNP promoter activity [18]. Different experimental settings, e.g. different cell types used for reporter assays, might account for this discrepancy. The results of Luo and coworkers were based on cotransfection of a 50-bp BNP-HRE promoter fragment together with HIF- $1 \alpha$ or HIF-1 $\alpha /$ VP16 expression vectors in HeLa cells. As mentioned above, we were not able to detect BNP mRNA in HeLa cells. We characterized the contribution of the CACAG motif using the hypoxia-inducible 967-bp BNP promoter construct in Hep3B cells. Since these cells express BNP endogenously, our approach may be more suitable to elucidate the regulatory pathways underlying the induction of the endogenous gene.

The involvement of HIF-1 $\alpha$ in the hypoxic upregulation of BNP underscores the protective aspect of the HIF response. Several studies indicate that BNP, in addition to its beneficial effects on cardiac workload, may act as an autocrine factor with antiproliferative, antifibrotic [7] and direct cytoprotective [5] properties. Thus, HIF-1 mediated BNP induction may be viewed as part of the local defense mechanism of the myocardium that limits hypoxic damage. Like other HIF target gene products such as EPO and HO-1, therapeutic application of BNP or induction by ischemic preconditioning may have protective effects under conditions of hypoxic injury [24, 47]. In this respect pharmacological inhibition of the HIF prolyl hydroxylases (PHDs), which stabilizes HIF- $\alpha$ and induces HIF target genes in vivo [34], is a promising strategy because it generates a cellular environment consisting of a plethora of protective factors in contrast to the administration of single target gene products. Recent data confirm the therapeutic principle that normoxic stabilization of HIF- $\alpha$ can ameliorate ischemic injury via activation of HIF target genes in the kidney [48]. In addition, PHD inhibition was shown to be effective in the heart and reduced cardiac remodeling after myocardial ischemia [49]. Thus, HIF represents an attractive molecular target in therapeutic approaches aiming at an amelioration of the cellular adaptation to low oxygen supply. Pharmacological HIF inducers may be used for a induction of HIF target genes including BNP to complement the endogenous response in order to limit myocardial tissue damage and prevent excessive cardiac remodeling. 
Acknowledgements: This work was supported by the German Research Foundation (DFG, SFB 423), the Interdisciplinary Center for Clinical Research (IZKF) at the University of Erlangen-Nuremberg and the Roche Foundation for Anaemia Research (RoFAR). We thank Hans Fees and Andrea Kosel for excellent technical assistance. 


\section{Bibliography}

1 Grantham, J. A., Borgeson, D. D. and Burnett, J. C., Jr. (1997) BNP: pathophysiological and potential therapeutic roles in acute congestive heart failure. Am. J. Physio.I 272, R1077-1083

2 Yamamoto, K., Burnett, J. C., Jr. and Redfield, M. M. (1997) Effect of endogenous natriuretic peptide system on ventricular and coronary function in failing heart. Am. J. Physio.I 273, H2406-2414

3 Song, D. L., Kohse, K. P. and Murad, F. (1988) Brain natriuretic factor. Augmentation of cellular cyclic GMP, activation of particulate guanylate cyclase and receptor binding. FEBS Lett. 232, 125-129

4 Cao, L. and Gardner, D. G. (1995) Natriuretic peptides inhibit DNA synthesis in cardiac fibroblasts. Hypertension 25, 227-234

5 D'Souza, S. P., Yellon, D. M., Martin, C., Schulz, R., Heusch, G., Onody, A., Ferdinandy, P. and Baxter, G. F. (2003) B-type natriuretic peptide limits infarct size in rat isolated hearts via KATP channel opening. Am. J. Physiol. Heart Circ. Physiol. 284, H1592-1600

6 Ikeda, M., Kohno, M., Yasunari, K., Yokokawa, K., Horio, T., Ueda, M., Morisaki, N. and Yoshikawa, J. (1997) Natriuretic peptide family as a novel antimigration factor of vascular smooth muscle cells. Arterioscler. Thromb. Vasc. Biol. 17, 731-736

7 Tamura, N., Ogawa, Y., Chusho, H., Nakamura, K., Nakao, K., Suda, M., Kasahara, M., Hashimoto, R., Katsuura, G., Mukoyama, M., Itoh, H., Saito, Y., Tanaka, I., Otani, H. and Katsuki, M. (2000) Cardiac fibrosis in mice lacking brain natriuretic peptide. Proc. Natl. Acad. Sci. U S A 97, 4239-4244

8 Kikuta, K., Yasue, H., Yoshimura, M., Morita, E., Sumida, H., Kato, H., Kugiyama, K., Ogawa, H., Okumura, K., Ogawa, Y. and Nakao, K. (1996) Increased plasma levels of B-type natriuretic peptide in patients with unstable angina. Am. Heart. J. 132, 101-107

9 Morita, E., Yasue, H., Yoshimura, M., Ogawa, H., Jougasaki, M., Matsumura, T., Mukoyama, M. and Nakao, K. (1993) Increased plasma levels of brain natriuretic peptide in patients with acute myocardial infarction. Circulation $\mathbf{8 8}$, 82-91

10 Mukoyama, M., Nakao, K., Saito, Y., Ogawa, Y., Hosoda, K., Suga, S., Shirakami, G., Jougasaki, M. and Imura, H. (1990) Increased human brain natriuretic peptide in congestive heart failure. N. Engl. J. Med. 323, 757-758

11 Liang, F., Wu, J., Garami, M. and Gardner, D. G. (1997) Mechanical strain increases expression of the brain natriuretic peptide gene in rat cardiac myocytes. J. Biol. Chem. 272, 28050-28056

12 Hama, N., Itoh, H., Shirakami, G., Nakagawa, O., Suga, S., Ogawa, Y., Masuda, I., Nakanishi, K., Yoshimasa, T., Hashimoto, Y. and et al. (1995) Rapid ventricular induction of brain natriuretic peptide gene expression in experimental acute myocardial infarction. Circulation 92, 1558-1564

13 He, Q., Wang, D., Yang, X. P., Carretero, O. A. and LaPointe, M. C. (2001) Inducible regulation of human brain natriuretic peptide promoter in transgenic mice. Am. J. Physiol. Heart Circ. Physiol. 280, H368-376

Hill, N. S., Klinger, J. R., Warburton, R. R., Pietras, L. and Wrenn, D. S. (1994) Brain natriuretic peptide: possible role in the modulation of hypoxic pulmonary hypertension. Am. J. Physiol. 266, L308-315 
15 Perhonen, M., Takala, T. E., Vuolteenaho, O., Mantymaa, P., Leppaluoto, J. and Ruskoaho, H. (1997) Induction of cardiac natriuretic peptide gene expression in rats trained in hypobaric hypoxic conditions. Am. J. Physiol. 273, R344-352

16 Toth, M., Vuorinen, K. H., Vuolteenaho, O., Hassinen, I. E., Uusimaa, P. A., Leppaluoto, J. and Ruskoaho, H. (1994) Hypoxia stimulates release of ANP and BNP from perfused rat ventricular myocardium. Am. J. Physiol. 266, $\mathrm{H} 1572-1580$

17 Goetze, J. P., Gore, A., Moller, C. H., Steinbruchel, D. A., Rehfeld, J. F. and Nielsen, L. B. (2004) Acute myocardial hypoxia increases BNP gene expression. Faseb J. 18, 1928-1930

18 Luo, Y., Jiang, C., Belanger, A., Akita, G., Wadsworth, S., Gregory, R. and Vincent, K. (2006) A Constitutively Active HIF-1a/VP16 Hybrid Factor Activates Expression of the Human B-Type Natriuretic Peptide Gene. Mol. Pharmacol. 69, 1953-1962

19 Semenza, G. L. (1998) Hypoxia-inducible factor 1 and the molecular physiology of oxygen homeostasis. J. Lab. Clin. Med. 131, 207-214

20 Wenger, R. H. (2002) Cellular adaptation to hypoxia: O2-sensing protein hydroxylases, hypoxia-inducible transcription factors, and O2-regulated gene expression. Faseb J. 16, 1151-1162

21 Bruick, R. K. and McKnight, S. L. (2001) A conserved family of prolyl-4hydroxylases that modify HIF. Science 294, 1337-1340

22 Epstein, A. C., Gleadle, J. M., McNeill, L. A., Hewitson, K. S., O'Rourke, J., Mole, D. R., Mukherji, M., Metzen, E., Wilson, M. I., Dhanda, A., Tian, Y. M., Masson, N., Hamilton, D. L., Jaakkola, P., Barstead, R., Hodgkin, J., Maxwell, P. H., Pugh, C. W., Schofield, C. J. and Ratcliffe, P. J. (2001) C. elegans EGL-9 and mammalian homologs define a family of dioxygenases that regulate HIF by prolyl hydroxylation. Cell 107, 43-54

23 Maxwell, P. H., Wiesener, M. S., Chang, G. W., Clifford, S. C., Vaux, E. C., Cockman, M. E., Wykoff, C. C., Pugh, C. W., Maher, E. R. and Ratcliffe, P. J. (1999) The tumour suppressor protein VHL targets hypoxia-inducible factors for oxygen-dependent proteolysis. Nature 399, 271-275

24 Cai, Z., Manalo, D. J., Wei, G., Rodriguez, E. R., Fox-Talbot, K., Lu, H., Zweier, J. L. and Semenza, G. L. (2003) Hearts from rodents exposed to intermittent hypoxia or erythropoietin are protected against ischemiareperfusion injury. Circulation 108, 79-85

25 Jurgensen, J. S., Rosenberger, C., Wiesener, M. S., Warnecke, C., Horstrup, J. H., Grafe, M., Philipp, S., Griethe, W., Maxwell, P. H., Frei, U., Bachmann, S., Willenbrock, R. and Eckardt, K. U. (2004) Persistent induction of HIF1alpha and-2alpha in cardiomyocytes and stromal cells of ischemic myocardium. Faseb J. 18, 1415-1417

26 Wiesener, M. S., Jurgensen, J. S., Rosenberger, C., Scholze, C. K., Horstrup, J. H., Warnecke, C., Mandriota, S., Bechmann, I., Frei, U. A., Pugh, C. W., Ratcliffe, P. J., Bachmann, S., Maxwell, P. H. and Eckardt, K. U. (2003) Widespread hypoxia-inducible expression of HIF-2alpha in distinct cell populations of different organs. Faseb J. 17, 271-273

27 Jiang, C., Lu, H., Vincent, K. A., Shankara, S., Belanger, A. J., Cheng, S. H., Akita, G. Y., Kelly, R. A., Goldberg, M. A. and Gregory, R. J. (2002) Gene expression profiles in human cardiac cells subjected to hypoxia or expressing a hybrid form of HIF-1 alpha. Physiol. Genomics 8, 23-32 
28 Wang, V., Davis, D. A., Haque, M., Huang, L. E. and Yarchoan, R. (2005) Differential gene up-regulation by hypoxia-inducible factor-1alpha and hypoxia-inducible factor-2alpha in HEK293T cells. Cancer Res 65, 3299-3306

29 Isenberg, G. and Klockner, U. (1982) Calcium tolerant ventricular myocytes prepared by preincubation in a "KB medium". Pflugers Arch. 395, 6-18

30 Volk, T., Nguyen, T. H., Schultz, J. H., Faulhaber, J. and Ehmke, H. (2001) Regional alterations of repolarizing $\mathrm{K}+$ currents among the left ventricular free wall of rats with ascending aortic stenosis. J. Physiol. 530, 443-455

31 Maxwell, P. H., Pugh, C. W. and Ratcliffe, P. J. (1993) Inducible operation of the erythropoietin 3' enhancer in multiple cell lines: evidence for a widespread oxygen-sensing mechanism. Proc. Natl. Acad. Sci. U S A 90, 2423-2427

Warnecke, C., Zaborowska, Z., Kurreck, J., Erdmann, V. A., Frei, U., Wiesener, M. and Eckardt, K. U. (2004) Differentiating the functional role of hypoxia-inducible factor (HIF)-1alpha and HIF-2alpha (EPAS-1) by the use of RNA interference: erythropoietin is a HIF-2alpha target gene in Hep3B and Kelly cells. Faseb J. 18, 1462-1464

33 Elbashir, S. M., Harborth, J., Lendeckel, W., Yalcin, A., Weber, K. and Tuschl, T. (2001) Duplexes of 21-nucleotide RNAs mediate RNA interference in cultured mammalian cells. Nature 411, 494-498

34 Warnecke, C., Griethe, W., Weidemann, A., Jurgensen, J. S., Willam, C., Bachmann, S., Ivashchenko, Y., Wagner, I., Frei, U., Wiesener, M. and Eckardt, K. U. (2003) Activation of the hypoxia-inducible factor-pathway and stimulation of angiogenesis by application of prolyl hydroxylase inhibitors. Faseb J. 17, 1186-1188

35 Rosenberger, C., Mandriota, S., Jurgensen, J. S., Wiesener, M. S., Horstrup, J. H., Frei, U., Ratcliffe, P. J., Maxwell, P. H., Bachmann, S. and Eckardt, K. U. (2002) Expression of hypoxia-inducible factor-1alpha and -2alpha in hypoxic and ischemic rat kidneys. J. Am. Soc. Nephrol. 13, 1721-1732

36 Lau, K. W., Tian, Y. M., Raval, R. R., Ratcliffe, P. J. and Pugh, C. W. (2007) Target gene selectivity of hypoxia-inducible factor-alpha in renal cancer cells is conveyed by post-DNA-binding mechanisms. Br. J. Cancer 96, 1284-1292

37 Semenza, G. L. and Wang, G. L. (1992) A nuclear factor induced by hypoxia via de novo protein synthesis binds to the human erythropoietin gene enhancer at a site required for transcriptional activation. Mol. Cell. Biol. 12, 5447-5454

38 Willam, C., Maxwell, P. H., Nichols, L., Lygate, C., Tian, Y. M., Bernhardt, W., Wiesener, M., Ratcliffe, P. J., Eckardt, K. U. and Pugh, C. W. (2006) HIF prolyl hydroxylases in the rat; organ distribution and changes in expression following hypoxia and coronary artery ligation. J. Mol. Cell. Cardiol. 41, 68-77

39 Yin, Z., Haynie, J., Yang, X., Han, B., Kiatchoosakun, S., Restivo, J., Yuan, S., Prabhakar, N. R., Herrup, K., Conlon, R. A., Hoit, B. D., Watanabe, M. and Yang, Y. C. (2002) The essential role of Cited2, a negative regulator for HIF1 alpha, in heart development and neurulation. Proc. Natl. Acad. Sci. U S A 99, 10488-10493

40 Harada, M., Saito, Y., Nakagawa, O., Miyamoto, Y., Ishikawa, M., Kuwahara, K., Ogawa, E., Nakayama, M., Kamitani, S., Hamanaka, I., Kajiyama, N., Masuda, I., Itoh, H., Tanaka, I. and Nakao, K. (1997) Role of cardiac nonmyocytes in cyclic mechanical stretch-induced myocyte hypertrophy. Heart Vessels Suppl 12, 198-200 
41 Kim, C. H., Cho, Y. S., Chun, Y. S., Park, J. W. and Kim, M. S. (2002) Early expression of myocardial HIF-1alpha in response to mechanical stresses: regulation by stretch-activated channels and the phosphatidylinositol 3-kinase signaling pathway. Circ. Res. 90, E25-33

42 Shyu, K. G., Lu, M. J., Chang, H., Sun, H. Y., Wang, B. W. and Kuan, P. (2005) Carvedilol modulates the expression of hypoxia-inducible factor-1alpha and vascular endothelial growth factor in a rat model of volume-overload heart failure. J. Card. Fail. 11, 152-159

43 Chang, H., Shyu, K. G., Wang, B. W. and Kuan, P. (2003) Regulation of hypoxia-inducible factor-1alpha by cyclical mechanical stretch in rat vascular smooth muscle cells. Clin. Sci. (Lond) 105, 447-456

44 Tian, H., McKnight, S. L. and Russell, D. W. (1997) Endothelial PAS domain protein 1 (EPAS1), a transcription factor selectively expressed in endothelial cells. Genes Dev. 11, 72-82

45 Chavez, J. C., Baranova, O., Lin, J. and Pichiule, P. (2006) The transcriptional activator hypoxia inducible factor 2 (HIF-2/EPAS-1) regulates the oxygendependent expression of erythropoietin in cortical astrocytes. J. Neurosci. 26, 9471-9481

46 Kimura, H., Weisz, A., Ogura, T., Hitomi, Y., Kurashima, Y., Hashimoto, K., D'Acquisto, F., Makuuchi, M. and Esumi, H. (2001) Identification of hypoxiainducible factor 1 ancillary sequence and its function in vascular endothelial growth factor gene induction by hypoxia and nitric oxide. J. Biol. Chem. 276, 2292-2298

47 Yet, S. F., Perrella, M. A., Layne, M. D., Hsieh, C. M., Maemura, K., Kobzik, L., Wiesel, P., Christou, H., Kourembanas, S. and Lee, M. E. (1999) Hypoxia induces severe right ventricular dilatation and infarction in heme oxygenase-1 null mice. J. Clin. Invest. 103, R23-29

48 Bernhardt, W. M., Campean, V., Kany, S., Jurgensen, J. S., Weidemann, A., Warnecke, C., Arend, M., Klaus, S., Gunzler, V., Amann, K., Willam, C., Wiesener, M. S. and Eckardt, K. U. (2006) Preconditional Activation of Hypoxia-Inducible Factors Ameliorates Ischemic Acute Renal Failure. J. Am. Soc. Nephrol. 17, 1970-1978

49 Philipp, S., Jurgensen, J. S., Fielitz, J., Bernhardt, W. M., Weidemann, A., Schiche, A., Pilz, B., Dietz, R., Regitz-Zagrosek, V., Eckardt, K. U. and Willenbrock, R. (2006) Stabilization of hypoxia inducible factor rather than modulation of collagen metabolism improves cardiac function after acute myocardial infarction in rats. Eur. J. Heart. Fail. 8, 347-354 


\section{Figure Legends}

Figure 1. BNP expression is induced by hypoxia and hypoxia mimetics in different cell lines and in rodent hearts in vivo. (A) RNase protection assay of cells exposed to $1 \% \mathrm{O}_{2}$ or $100 \mu \mathrm{M}$ 2,2'dipyridyl (DP) for $16 \mathrm{~h}$. BNP is upregulated in human hepatoma Hep3B and HepG2 cells, human renal tubular epithelial HKC-8 cells and in the mouse preadipocyte cell line 3T3L1. (B) Induction of BNP mRNA expression was already detectable after $4 \mathrm{~h}$ of DP-stimulation in Hep3B and HKC-8 cells. (C) In isolated adult rat cardiomyocytes BNP mRNA expression was also significantly upregulated after hypoxic incubation. (D) Exposure to $0.1 \%$ carbon monoxide for $8 \mathrm{~h}$ significantly increased BNP mRNA abundance in rat and mouse hearts. All figures are representative results of three independent experiments; U6 small nuclear RNA (U6sn) served as loading control.

Table 1. Putative hypoxia-response elements (HRE) in the promoter of the human BNP gene. Nucleotide positions are given relative to the transcriptional start site. The HIF binding sequence 5'-RCGTG-3' is indicated in bold letters. For comparison the HREs of the human EPO and VEGF genes are shown. Note that the HIF ancillary sequence (HAS; 5'-CACAG3'), which is also present in the EPO enhancer, was found only in close proximity of BNPHRE 2, but not of other putative HREs.

Figure 2. Hypoxia activates human BNP promoter reporter constructs. In transient transfections, luciferase activity of (A) a 2027-bp BNP promoter fragment (hBNP-Prom(L)) and of (B) a 5'-deleted 967-bp promoter (hBNP-Prom) were significantly increased after stimulation with hypoxia $\left(1 \% \mathrm{O}_{2}\right)$ or $100 \mu \mathrm{M} 2,2^{\prime}$ dipyridyl (DP), with a more pronounced activation of the 967-bp construct $\left({ }^{*} \mathrm{p}<0.05\right.$ vs. wt). (C,D) Each HRE was mutated individually in the shorter 967-bp hBNP-Prom construct. The increase of luciferase activity of each construct after exposure to hypoxia or DP was related to its basal activity. Mutation of BNP-HRE 2 significantly reduced the induction after both hypoxic and DP-stimulation, respectively. Data are means of three independent experiments $\pm \mathrm{SD}$; $\left({ }^{*} \mathrm{p}<0.05\right.$ vs. wt induced).

Figure 3. Identification of the functional HIF-1 binding site in the human BNP promoter using gel-shift assays (EMSA) and chromatin immunoprecipitation (ChIP). (A) Specific 
binding of hypoxic or DP-stimulated nuclear proteins from Hep3B cells was detected with a BNP-HRE 2 probe, but not with normoxic proteins, or the mutated BNP-HRE 2. (B) The hypoxia induced specific complex was supershifted by preincubation with a monoclonal antibody against HIF-1 $\alpha$, indicating that HIF- $1 \alpha$ was part of the inducible complex binding to BNP-HRE 2. (C) ChIP with a HIF-1 $\alpha$ antibody demonstrated a marked enrichment of a BNP promoter fragment spanning HRE 2 in DP-treated Hep3B cells compared to untreated cells or cells incubated with an unspecific rabbit IgG antibody (upper panel). Amplification of a promoter fragment of the known HIF target carbonic anhydrase IX containing a functional HRE (CA9, middle panel) and of a sequence of the $\beta$-actin gene lacking a HRE (lower panel) were used as positive and negative controls, respectively. (D) The BNP promoter fragment (upper panel) and the $\beta$-actin gene fragment (lower panel) were not specifically enriched by PCR after chromatin immunoprecipitation with the HIF-2 $\alpha$ antibody, the CA9 promoter fragment was (middle panel). Representative of three independent experiments.

Figure 4. SiRNA-mediated knockdown of HIF-1 $\alpha$ reduces BNP expression and BNP promoter-driven reporter gene activity. Both HIF- $\alpha$ mRNA (A) and protein levels (B) are effectively reduced after siRNA knockdown of the respective isoform in Hep3B cells. (A) BNP mRNA induction in Hep3B cells was significantly reduced after knockdown of HIF-1 $\alpha$. Knockdown of HIF-2 $\alpha$ had no effect. (C) BNP mRNA induction was also HIF-1 $\alpha$ dependent in HKC-8 cells. (A) and (C) are representative pictures of three independent experiments. (D) Reporter activity of the 967-bp hBNP-Prom construct stimulated with DP was significantly reduced after knockdown of HIF-1 $\alpha$, whereas HIF-2 $\alpha$ siRNA-transfection had no effect $\left({ }^{*} p<0.05\right.$ vs. wt induced). Note that luc siRNA is specific for the pGL3 vector and does not interfere with the luciferase sequence contained in hBNP-Prom (pGL2 vector backbone). (E) BNP mRNA expression was inducible only in wt MEF expressing functional HIF-1 $\alpha$, but not in HIF-1 $\alpha$-deficient cells $\left(\mathrm{MEF}^{\mathrm{HIF-1 \alpha --/}}\right)$.

Figure 5. A CACAG motif upstream of the BNP-HRE is required for maximum hypoxic hBNP promoter activity. (A) Mutation of the CACAG-sequence 27 bp upstream of HRE 2 in the hBNP promoter reporter construct significantly reduced induction of promoter activity by DP (* $\mathrm{p}<0.05$ vs. wt induced). Mutation of HRE 2 almost completely abolished promoter 
activation (\#p<0.05 CACAG mut vs. HRE 2 mut). Therefore, inactivation of both sequences did not further affect promoter activity. Data are means of three independent experiments \pm SD. (B) EMSA revealed a constitutive binding complex when the oligonucleotide probe containing the CACAG motif was incubated with nuclear extracts (NE). The complex disappeared after mutation of the binding motif from CACAG to AATAA, indicating the specificity of the binding complex for the pentanucleotide sequence. 
R. Biochemical Journal Immediate Publication. Published on 7 Sep 2007 as manuscript BJ20070629 Figure 1.

A

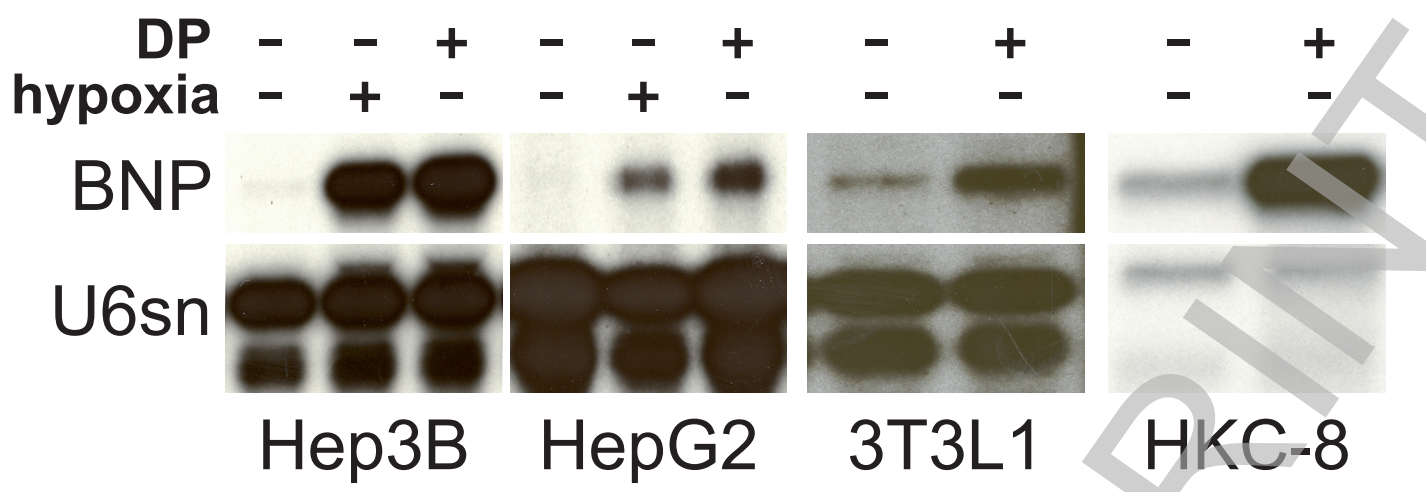

B

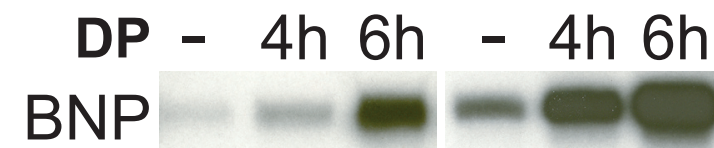

hypoxia - +

BNP

U6sn

Hep3B HKC-8

U6sn

rat cardiomyocytes

D

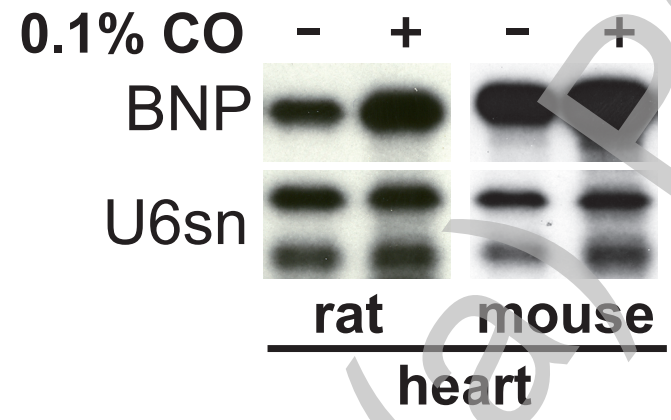




\section{Table 1.}

\begin{tabular}{|l|c|c|c|c|}
\hline & Location & Sequence 5' $\mathbf{3}$ 3' & Direction & Ancillary Sequence \\
\hline \hline & & & & No \\
\hline & $-1158 \mathrm{nt}$ & G GCGTG AT & sense & No \\
\hline & $-877 \mathrm{nt}$ & C ACGTG GA & sense & No \\
\hline BNP-HRE 1 & $-626 \mathrm{nt}$ & TC CACGC A & antisense & No \\
\hline BNP-HRE 2 & $-466 \mathrm{nt}$ & T ACGTG CG & sense & CACAG (-492 nt) \\
\hline BNP-HRE 3 & $-363 \mathrm{nt}$ & CT CACGT C & antisense & No \\
\hline BNP-HRE 4 & $-147 \mathrm{nt}$ & CC CACGT C & antisense & CACAG \\
\hline & & & & AACAG \\
\hline hEpo-HRE & & T ACGTG CT & & \\
\hline hVEGF-HRE & & T ACGTG GG & & AACA \\
\hline
\end{tabular}


R. Biochemical Journal Immediate Publication. Published on 7 Sep 2007 as manuscript BJ20070629

${ }^{B} J_{\text {Figure } 2 .}$.
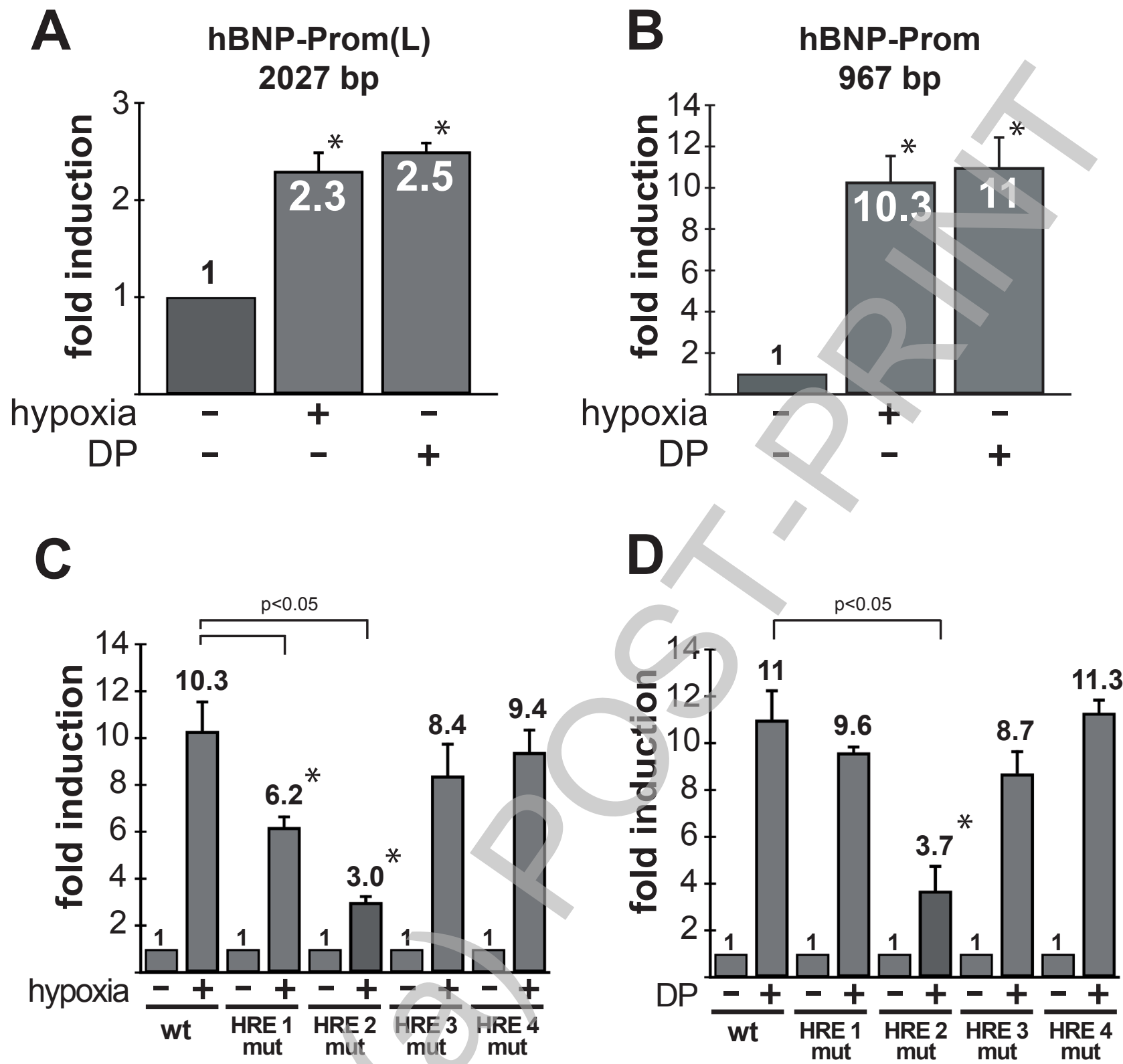
R. Biochemical Journal Immediate Publication. Published on 7 Sep 2007 as manuscript BJ20070629 Figure 3.
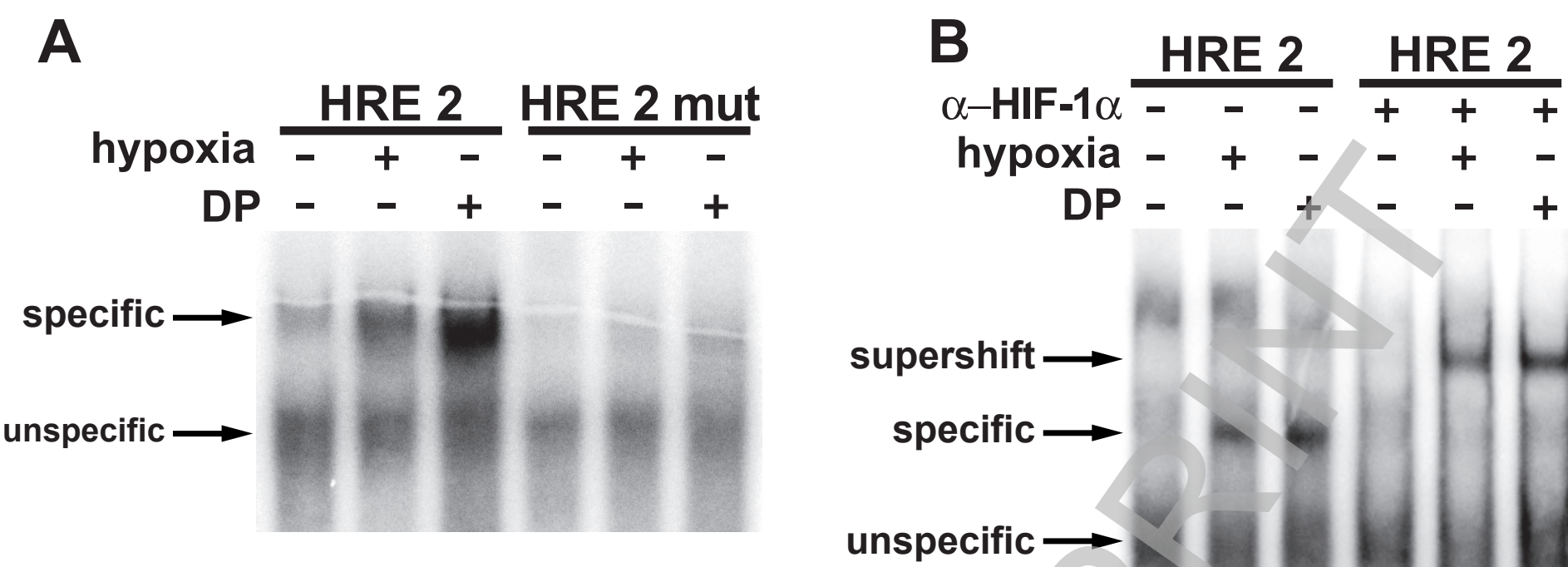

C

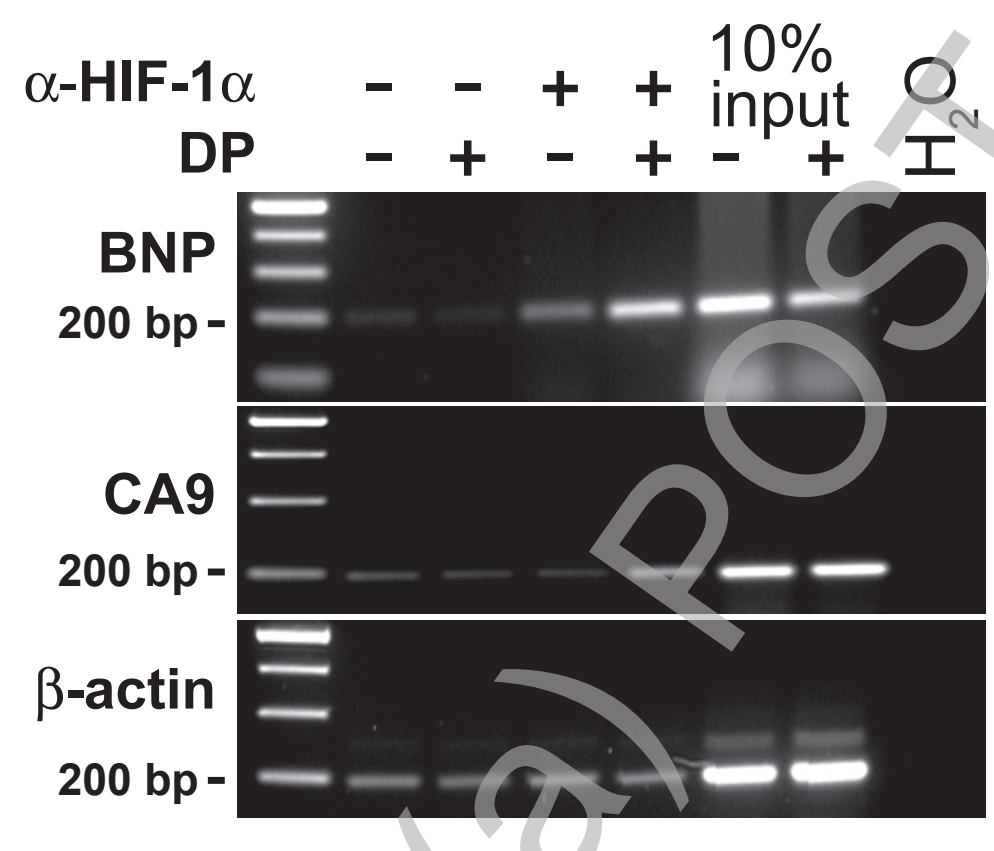

D

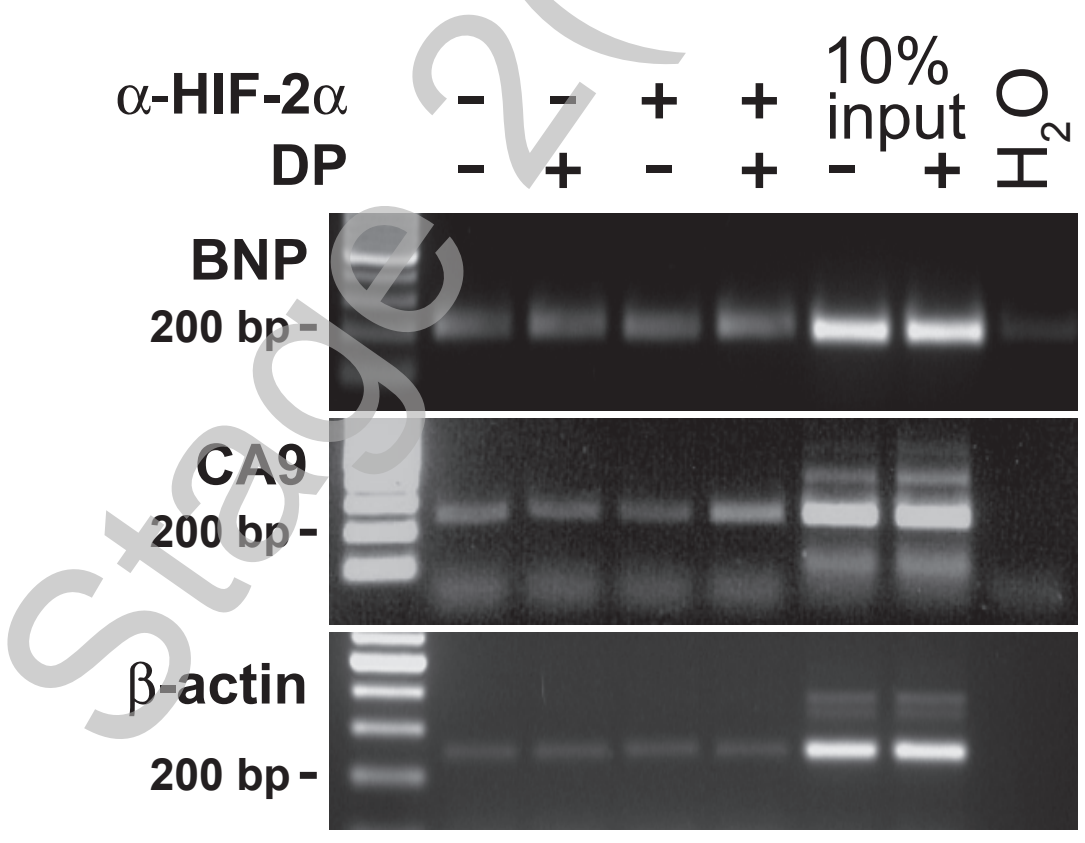




\section{R. Biochemical Journal Immediate Publication. Published on 7 Sep 2007 as manuscript BJ20070629}

Figure 4.

A

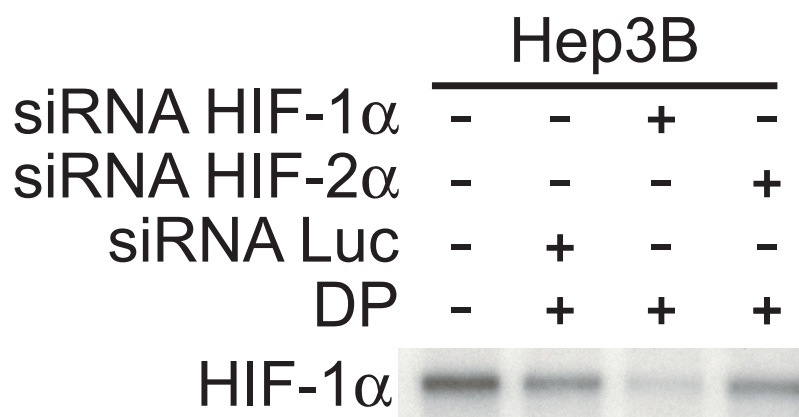

HIF-2 $\alpha$

hBNP

U6sn

D

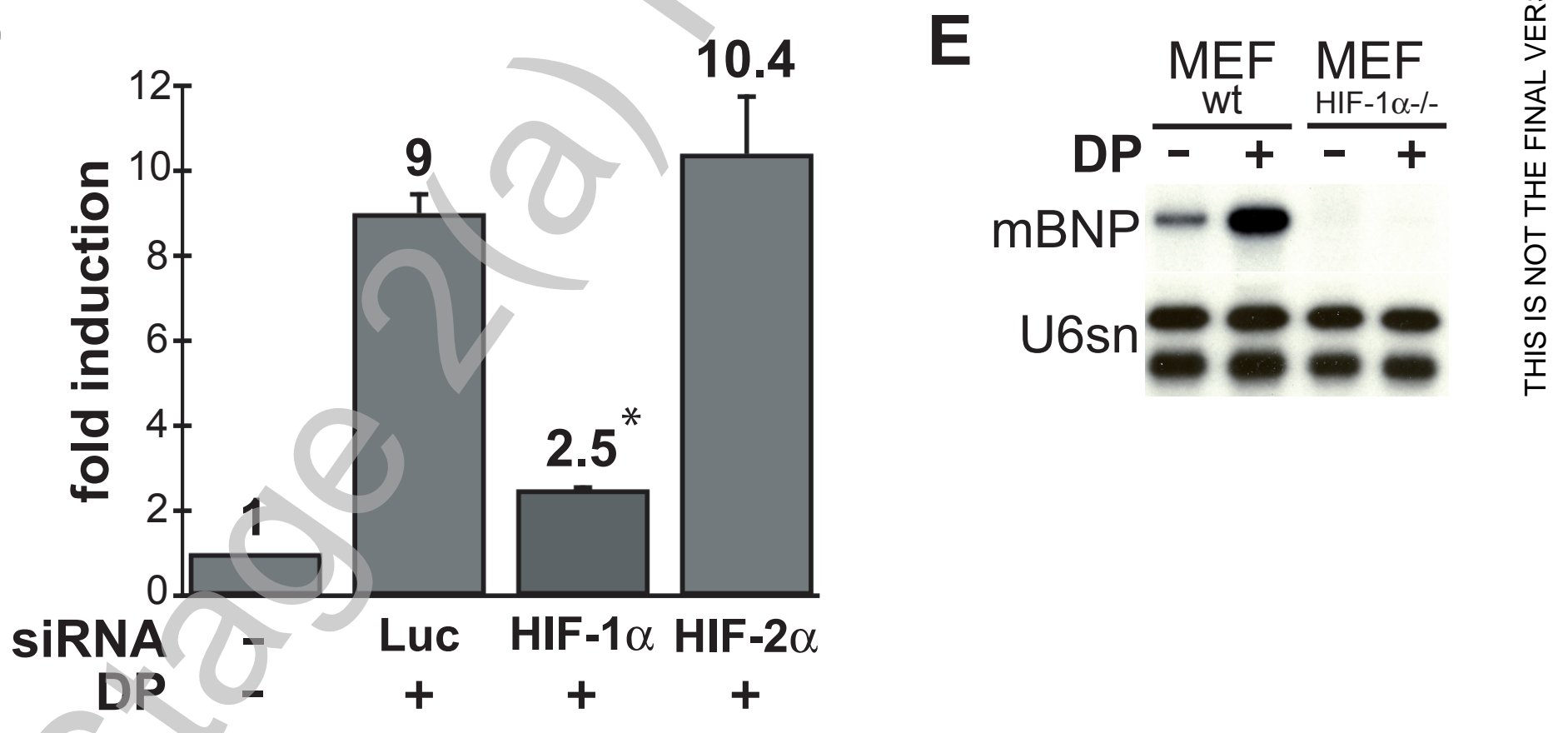

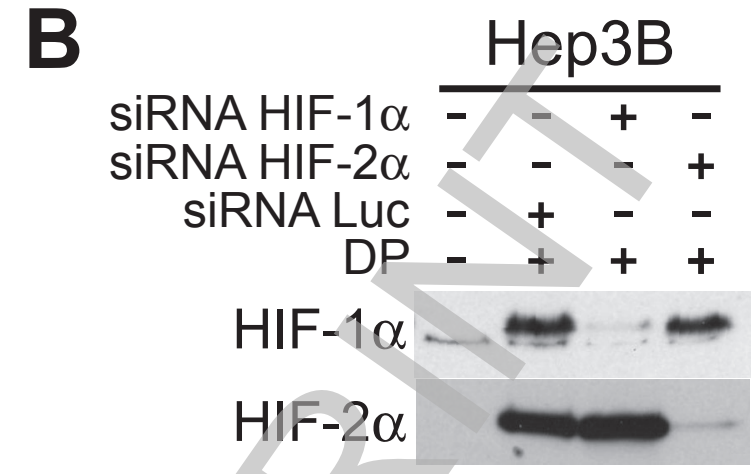

C SiRNAHIF-1 $\alpha$ - $\quad-\quad+\quad-$ SiRNAHIF-2 $\alpha$ - $\quad$ - $\quad$ - $\quad+$ SIRNALUC - + - -

$\mathrm{DP}-\quad+\quad+$

hBNP

U6sn 
Biochemical Journal Immediate Publication. Published on 7 Sep 2007 as manuscript BJ20070629

Figure 5.

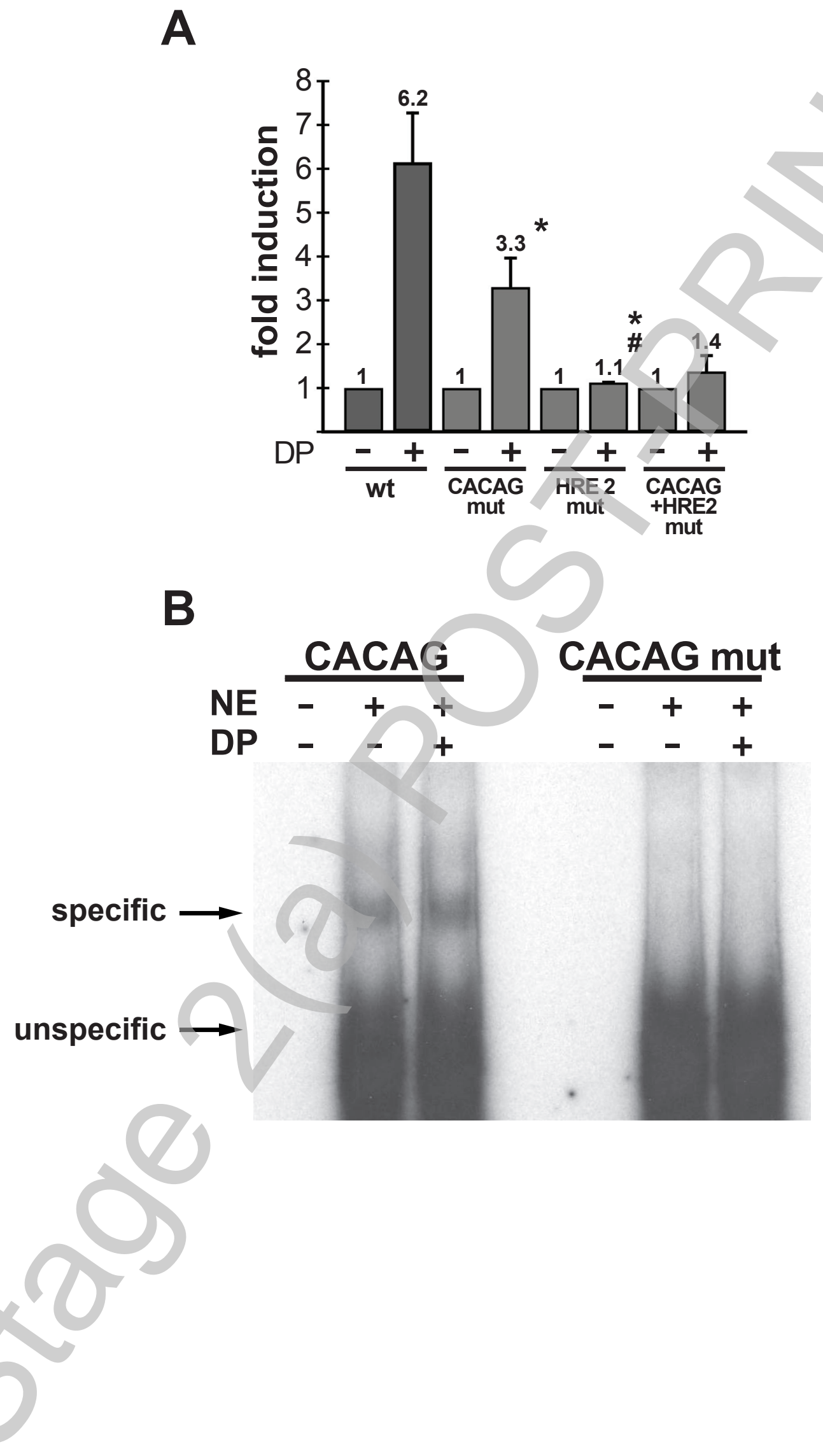

Licenced copy. Copying is not permitted, except with prior permission and as allowed by law. (C) 2007 The Authors Journal compilation (C) 2007 Biochemical Society 